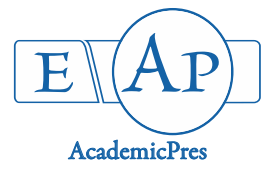

\title{
Performance and Quality of Muskmelon (Cucumis melo L.) as Influenced by Crop Spacing and Rates of Swine Manure Application
}

\author{
Ehizogie J. FALODUN*, Sunday A. OGEDEGBE \\ University of Benin, Department of Crop Science,Nigeria; ehizogie.falodun@uniben.edu ("corresponding author); sundayogedegbe@uniben.edu
}

\begin{abstract}
Field and laboratory studies were conducted to determine the effect of plant spacing and rate of swine manure application on the growth, yield, nutrient concentration, uptake and proximate composition of muskmelon (Cucumis melo). The experiments were laid out as a $3 \times 4$ factorial fitted in a randomized complete block design (RCBD) with 3 replications. The treatments consisted of four rates of swine manure $\left(0 \mathrm{tha}^{-1}, 5 \mathrm{tha}^{-1}, 10 \mathrm{tha} \mathrm{h}^{-1}\right.$ and $\left.15 \mathrm{t} \mathrm{ha} \mathrm{h}^{-1}\right)$ and three crop spacing $(50 \times 50 \mathrm{~cm}$, $75 \times 75 \mathrm{~cm}, 100 \times 100 \mathrm{~cm}$ ). The results showed that spacing had no significant effect on the number of leaves, leaf area, stem diameter and number of branches, but substantially increased the vine length at $100 \times 100 \mathrm{~cm}$. Number of flowers and fruit weight per plant increased with raw spacing, while the number of fruits per plot and fruit yield $\left(t \mathrm{ha}^{-1}\right)$ increased with a decrease in plant spacing, whereas the narrowest spacing of $50 \times 50 \mathrm{~cm}$ produced the significantly highest fruit yield $(25.47 \mathrm{t}$ $\left.\mathrm{ha}^{-1}\right)$. The concentrations of $\mathrm{P}, \mathrm{Ca}, \mathrm{Mg}$ and $\mathrm{Fe}\left(4.28,6.81,4.55\right.$ and $\left.0.80 \mathrm{mg} \mathrm{kg}^{-1}\right)$ were the highest at $100 \times 100 \mathrm{~cm}$ spacing compared to other treatments. However, $\mathrm{N}$ concentration (1.18) and uptake of N, P, Ca, Mg, Fe and $\mathrm{Na}$ was highest at spacing of $75 \times 75 \mathrm{~cm}$ and at $10 \mathrm{t} \mathrm{ha}^{-1}$ swine manure rate. The effect of spacing on proximate composition of muskmelon did not follow a particular pattern; however, wider spacing of $75 \times 75 \mathrm{~cm}$ and $100 \times 100 \mathrm{~cm}$ at $10 \mathrm{t} \mathrm{ha}{ }^{-1}$ favoured most of the proximate composition compared to the narrowest spacing of $50 \times 50 \mathrm{~cm}$ and other manure rates. Although there was no significant difference in fruit yields of 10 and $15 \mathrm{tha}^{-1}$, application of $15 \mathrm{tha}^{-1}$, swine manure out-yielded $10 \mathrm{tha}^{-1}$, by $8.55 \%$.
\end{abstract}

Keywords: flowers; fruit; muskemelon; nutrients; vine length

\section{Introduction}

Muskmelon (Cucumis melo) belongs to the family Curcurbitaceae. It is an annual plant with a trailing vine growth. The fruits are an extremely healthful food choice (Hodges and Lester, 2006). They could serve protective roles in reducing chronic diseases such as cancer and cardiovascular disease. Muskmelon is rich in bioactive compounds such as phenolics, flavonoids and vitamins, as well as carbohydrates and minerals (especially potassium). In addition, it is low in fat and calories (about $17 \mathrm{kcal} / 100$ g) and contains a large amount of dietary fibre, $90 \%$ water and $9 \%$ carbohydrates, with less than $1 \%$ of protein and fat respectively (USDA, 2014).

Inspite of the usefulness of this crop, the yield is still low due to under cultivation at a large scale and also poor agronomic practices which include incorrect spacing, pest and disease infestation, infertile soil, over reliance on inorganic fertilizer, amongst others.

Excessive reliance on mineral fertilizers has been associated with environmental and economic problems during the past decades (Cakmak, 2002). Thus organic farming has emerged as a sustainable agricultural approach that includes economic, environmental, and social measures (Pacini et al., 2003). Recent studies showed that the yield of organically grown melon crops can be similar or higher than that of conventionally grown melons (Bullock et al., 2002; Fernandes et al., 2003; Morra et al., 2003; Curuk et al., 2004; Melero et al., 2006). The application of organic matter can affect plant growth by providing the soil with various forms of nitrogen $(\mathrm{N})$, as well as hormone-like compounds (Picolo et al., 1992). El-Desuki et al. (2000) reported that organic manure addition at higher level (20 $\mathrm{m}^{3} /$ fed.) improved plant growth, NPK content, total yield and fruit quality. Numerous researchers have reported yield increase due to reduction in both plant and row spacing of muskmelon (Davis and Manert, 1965; Knavel, 1991; Maynard and Scott, 1998).

In light of the above, the objective of the present study was to determine the effect of crop spacing and swine manure application on the growth, yield, nutrient concentration, uptake and proximate composition of muskmelon. 


\section{Materials and Methods}

\section{Soilproperties}

The studies were carried out at the Experimental Farm and at the Central Laboratory, Faculty of Agriculture, University of Benin, Benin City, Nigeria. The location lies between latitude $614^{\prime} \mathrm{N}$ and $74^{\prime} \mathrm{N}$ and longitude $5^{\circ} 40^{\prime} \mathrm{E}$ and $643^{\prime} \mathrm{E}$. The experimental field was manually cleared and debris worked into the soil. Prior to planting, composite soil samples were collected from a depth of $0-30 \mathrm{~cm}$, using soil auger and swine manure were also collected. Samples were air-dried and packaged for routine soil physicochemical analysis. Soil $\mathrm{pH}$ was determined using a $\mathrm{pH}$ meter. Organic carbon was determined by wet oxidation method (Walkley and Black, 1962) as modified by Jackson (1969). Total nitrogen was obtained by macro Kjeldahl method as modified by Jackson (1969). Available P was extracted by Bray I method (Bray and Kurtz, 1945) and P was estimated by the blue colour method of Murphy and Riley (1962). Exchangeable $\mathrm{K}$ and $\mathrm{Na}$ were determined using flame photometer, while $\mathrm{Ca}$ and $\mathrm{Mg}$ were determined using the Atomic Absorption Spectrophotometer. The results of the soil analysis and swine manure are presented in Table 1 .

\section{Experimental design}

The experiment was laid out in a $3 \times 4$ factorial arrangement fitted into a randomized complete block design (RCBD) with 12 treatments replicated 3 times. The treatments were based on rates of organic manure application ( $0 \mathrm{t} \mathrm{ha}^{-1}, 5 \mathrm{tha}^{-1}, 10 \mathrm{tha}^{-1}$ and $\left.15 \mathrm{t} \mathrm{ha}^{-1}\right)$ and different plant spacing $(50 \times 50 \mathrm{~cm}, 75 \times 75 \mathrm{~cm}$ and $100 \times$ $100 \mathrm{~cm}$ ). The swine manure used for the experiment was incorporated into their respective plots, depending on the treatment, and left for two weeks before sowing; three seeds were sown per hole and latter thinned to one seedling per stand at a spacing of $50 \times 50 \mathrm{~cm}, 75 \times 75 \mathrm{~cm}$ and $100 \times 100$ $\mathrm{cm}$, giving a plant population of $1,440,000 ; 266,429$ and 90,000 plants/ha respectively. Plots were mulched with dry grasses to conserve moisture and weeding was carried out 2 and 6 weeks after planting (WAP).

\section{Data collection}

Four plants were randomly tagged per plot for data collection. Data were collected on vine length $(\mathrm{cm})$, number of leaves, number of branches, leaf area $(\mathrm{cm})$ and stem diameter $(\mathrm{cm})$ at 4 WAP and commenced until 7 WAP, while data for the number of flowers, number of fruits, fruit fresh weight $(\mathrm{g})$, fruit diameter $(\mathrm{cm})$ and fruit yield $\left(\mathrm{t} \mathrm{ha} \mathrm{a}^{-1}\right)$ were taken between 8 - 15 WAP.

Determination of nutrient concentration and uptake and proximate composition of muskmelon fruits

At harvest, fruits were collected from each of the plots, washed and chopped into small bits, labelled as samples and oven dried at a temperature of $70{ }^{\circ} \mathrm{C}$ for 48 hours. After, they were crushed in preparation for laboratory analysis.

Proximate analysis was carried out using the methods of AOAC (1990). The Crude Protein content was also determined using the micro-kjeldahl method as described by AOAC (1990). The mineral elements N, P, Ca, Mg, Fe, $\mathrm{Na}$, were analysed using standard laboratory procedures The mineral uptake were the product of the oven dry weight of the tissues and the corresponding value of the nutrient in the tissues.

\section{Statistical analysis}

Data collected were subjected to analysis of variance (ANOVA), using SAS (Statistical Analysis Software) and least significance difference (LSD) test at 5\% level of probability was use to compare the significant treatment mean.

Table 1. Physical and chemical analysis of soil prior to planting and chemical properties of swine manures used

\begin{tabular}{|c|c|c|}
\hline Parameters & Soil & Swine manure \\
\hline $\mathrm{pH}$ & 5.40 & 6.41 \\
\hline Total Nitrogen $\left(\mathrm{g} \mathrm{kg}^{-1}\right)$ & 0.03 & 1.46 \\
\hline Available Phosphorus $\left(\mathrm{mg} \mathrm{kg}^{-1}\right)$ & 11.52 & 8.34 \\
\hline Potassium $\left(\mathrm{cmol} \mathrm{kg}^{-1}\right)$ & 0.32 & 0.65 \\
\hline Calcium $\left(\mathrm{cmol} \mathrm{kg}^{-1}\right)$ & 0.88 & 0.83 \\
\hline Magnesium $\left(\mathrm{cmol} \mathrm{kg}^{-1}\right)$ & 0.32 & 0.63 \\
\hline Sodium $\left(\mathrm{cmol} \mathrm{kg}^{-1}\right)$ & 0.23 & 0.34 \\
\hline Hydrogen $\left(\mathrm{cmol} \mathrm{kg}^{-1}\right)$ & 0.65 & - \\
\hline Aluminium $\left(\mathrm{cmol} \mathrm{kg}^{-1}\right)$ & 0.06 & - \\
\hline Organic carbon $\left(\mathrm{g} \mathrm{kg}^{-1}\right)$ & 20.37 & - \\
\hline Sulphur $\left(\mathrm{mg} \mathrm{kg}^{-1}\right)$ & 8.44 & - \\
\hline Sand $(\%)$ & 88.20 & - \\
\hline Silt (\%) & 4.62 & - \\
\hline Clay $(\%)$ & 7.18 & - \\
\hline Organic matter $(\%)$ & 20.37 & 32.62 \\
\hline ECEC & 2.46 & - \\
\hline Textural class & Sandy loam & \\
\hline
\end{tabular}




\section{Results}

The soil had a sand content of $88.22 \%, 4.62 \%$ silt and $7.18 \%$ clay. Organic matter was low (3.5\%), while the $\mathrm{pH}$ was slightly acidic (5.4), with a total nitrogen content of $0.03 \mathrm{~g} / \mathrm{kg}$. The results of the swine manure showed that it is a rich source of primary plant nutrients adequate for crop production (Table 1). The effect of spacing on vine length was significant. The widest spacing of $100 \times 100 \mathrm{~cm}$ produced the longest vine length $(46.82 \mathrm{~cm})$, followed by 50 $\times 50 \mathrm{~cm}$ spacing $(40.32 \mathrm{~cm})$, while $75 \times 75 \mathrm{~cm}$ spacing $(32.53 \mathrm{~cm})$ had the shortest vine length (Table 2). Application of $10 \mathrm{t} / \mathrm{ha}$ and $15 \mathrm{t} / \mathrm{ha}$ swine manure significantly increased vine length $(30.91 \mathrm{~cm}$ and $33.91 \mathrm{~cm})$ respectively above the control $(17.02 \mathrm{~cm})$. Number of leaves and branches were not significantly influenced by spacing. Number of leaves and branches increased with increase in swine manure application from $0 \mathrm{t} \mathrm{ha}^{-1}$ to $15 \mathrm{t} \mathrm{ha}^{-1}$. The effect of spacing and swine manure application were not significant for leaf area and stem diameter. Plant spacing and swine manure significantly influenced yield and yield components except spacing on number of fruit/plant and fruit diameter (Table 3). The narrowed spacing had significantly higher fruits/plot and fruit yield per ha, while yield and yield components increased with higher swine manure applied. Swine manure application rate had no effect on the number of flowers of muskmelon. Swine manure increased the number of fruits from $0 \mathrm{t} \mathrm{ha}^{-1}$ up to 10 $\mathrm{t} \mathrm{ha}^{-1}$, while a further increase in manure rate did not result in a significant increase in number of fruits per plant. Number of fruits per plot decreased with increasing raw spacing and increased with increasing manure application rate. Fruit weight per plant did not follow a particular pattern; however, $75 \times 75 \mathrm{~cm}$ produced significantly highest fruit weight $(429.08 \mathrm{~g})$ per plant, above $100 \times 100 \mathrm{~cm}$ $(350.13 \mathrm{~g})$ and $50 \times 50 \mathrm{~cm}(318.16 \mathrm{~g})$ which were statistically similar. Application of $10 \mathrm{t} \mathrm{ha}^{-1}$ and $15 \mathrm{t} \mathrm{ha}^{-1}$ significantly produced the highest fruit weight per plant, above $0 \mathrm{t} \mathrm{ha} \mathrm{a}^{-1}$ and $5 \mathrm{tha}$. The fruit yield $\left(\mathrm{tha}^{-1}\right)$ decreased with an increase in spacing, whereas significantly the highest fruit yield $\left(25.47 \mathrm{t} \mathrm{ha}^{-1}\right)$ was obtained at the narrowest spacing of $50 \times 50 \mathrm{~cm}$, followed by $14.34 \mathrm{t} \mathrm{ha}^{-1}$ at $75 \times 75$ $\mathrm{cm}$ and the lowest fruit yield $\left(7.01 \mathrm{t} \mathrm{ha}^{-1}\right)$ was obtained at the widest spacing of $100 \times 100 \mathrm{~cm}$.

Although, the effect of spacing on proximate composition of muskmelon did not follow a particular pattern; the wider spacing of $75 \times 75 \mathrm{~cm}$ and $100 \times 100 \mathrm{~cm}$ significantly improve the quality of muskmelon, more than $50 \times 50 \mathrm{~cm}$ spacing. The effect of spacing on moisture content and crude protein content of muskemelon was not discernible; however, the application of manure increased their contents from $0-10 \mathrm{tha}^{-1}$. The significantly $(\mathrm{P}<0.01)$ high moisture content of muskemelon fruits in this experiment shows that muskemelon have a high moisture content (\%), which ranged between $92.79-99.06 \%$. The ash content, ether extract and crude fibre contents increased with increase in spacing and with increase in manure application up to $10 \mathrm{t} \mathrm{ha}^{-1}$, but decreased at $15 \mathrm{tha}^{-1}$ manure rate applications. There was no discernible pattern observed for nitrogen extract content with plant spacing and manure application; wider spacing of $100 \times 100 \mathrm{~cm}$ tends to favour most of the proximate parameters measured except percentage of nitrogen free extract (Table 4). Similarly, the wider spacing of $100 \times 100 \mathrm{~cm}$ increased the concentration of most nutrients in muskemelon compared to the narrower spacing, except for nitrogen and sodium. Similarly, the nutrient concentration increased with increase in manure application up to $10 \mathrm{t} \mathrm{ha}^{-1}$ except for sodium. The highest uptake of most nutrient elements studied was obtained at $75 \times 75 \mathrm{~cm}$ spacing, except for sodium and decreased at 100 $\times 100 \mathrm{~cm}$ spacing, except for iron, which was the highest at $75 \times 75 \mathrm{~cm}$. In all the nutrients studied, the application of $10 \mathrm{t} \mathrm{ha}^{-1}$ recorded the highest nutrient uptake which decreased with a further increase in manure rate to $15 \mathrm{t} \mathrm{ha}^{-1}$.

Table 2. Effect of spacing and swine manure on some vegetative parameters of muskmelon (Cucumis melo L.)

\begin{tabular}{|c|c|c|c|c|c|}
\hline Treatments & $\begin{array}{l}\text { Vine length } \\
(\mathrm{cm})\end{array}$ & $\begin{array}{l}\text { No. of } \\
\text { leaves }\end{array}$ & $\begin{array}{c}\text { Leaf area } \\
\left(\mathrm{cm}^{2}\right)\end{array}$ & $\begin{array}{c}\text { Stem diameter } \\
(\mathrm{cm})\end{array}$ & $\begin{array}{c}\text { No. of } \\
\text { branches }\end{array}$ \\
\hline \multicolumn{6}{|l|}{$\begin{array}{l}\text { Plants spacing } \\
(\mathrm{cm})\end{array}$} \\
\hline $50 \times 50$ & $40.32^{\mathrm{ab}}$ & $35.60^{a}$ & $84.25^{a}$ & $0.29^{\mathrm{a}}$ & $2.40^{a}$ \\
\hline $75 \times 75$ & $32.53^{b}$ & $34.56^{a}$ & $90.92^{a}$ & $0.35^{\mathrm{a}}$ & $2.11^{\mathrm{a}}$ \\
\hline $100 \times 100$ & $46.82^{a}$ & $24.49^{\mathrm{a}}$ & $78.48^{a}$ & $0.25^{\mathrm{a}}$ & $1.89^{\mathrm{a}}$ \\
\hline Significance & ${ }^{*}$ & NS & NS & NS & NS \\
\hline LSD & 14.22 & 13.74 & 32.03 & 0.11 & 0.89 \\
\hline \multicolumn{6}{|l|}{$\begin{array}{l}\text { Swine manure } \\
\qquad\left(\mathrm{tha}^{-1}\right)\end{array}$} \\
\hline 0 & $17.02^{\mathrm{b}}$ & $21.82^{b}$ & $68.01^{\mathrm{a}}$ & $0.30^{\mathrm{a}}$ & $1.49^{\mathrm{b}}$ \\
\hline 5 & $24.79^{\mathrm{ab}}$ & $28.75^{\mathrm{ab}}$ & $74.26^{\mathrm{a}}$ & $0.25^{a}$ & $2.29^{\mathrm{ab}}$ \\
\hline 10 & $30.91^{\mathrm{a}}$ & $36.27^{\mathrm{ab}}$ & $93.71^{a}$ & $0.30^{a}$ & $2.19^{\mathrm{ab}}$ \\
\hline 15 & $33.91^{\mathrm{a}}$ & $39.37^{\mathrm{a}}$ & $102.21^{\mathrm{a}}$ & $0.34^{\mathrm{a}}$ & $2.57^{\mathrm{a}}$ \\
\hline Significance & ${ }^{*}$ & ${ }^{*}$ & NS & NS & $*$ \\
\hline LSD & 13.84 & 15.87 & 36.99 & 0.13 & 1.03 \\
\hline
\end{tabular}


294

Table 3. Effect of spacing and swine manure on yield and yield components of muskmelon

\begin{tabular}{|c|c|c|c|c|c|c|}
\hline Treatments & No. of flowers/ plant & No. of fruits/plant & No. of fruits/plot & Fruit weight/plant $(\mathrm{g})$ & Fruit diameter $(\mathrm{cm})$ & Fruit yield ( $\mathrm{t} / \mathrm{ha})$ \\
\hline \multicolumn{7}{|c|}{ Plants spacing $(\mathrm{cm})$} \\
\hline $50 \times 50$ & $3.42^{\mathrm{b}}$ & $1.47^{\mathrm{a}}$ & $71.83^{\mathrm{a}}$ & $318.16^{\mathrm{b}}$ & $14.20^{a}$ & $25.47^{\mathrm{a}}$ \\
\hline $75 \times 75$ & $7.45^{\mathrm{a}}$ & $1.58^{\mathrm{a}}$ & $31.25^{\mathrm{b}}$ & $429.08^{a}$ & $14.57^{\mathrm{a}}$ & $14.34^{\mathrm{b}}$ \\
\hline $100 \times 100$ & $1.67^{\mathrm{b}}$ & $1.63^{\mathrm{a}}$ & $19.50^{\mathrm{b}}$ & $350.13^{b}$ & $17.66^{\mathrm{a}}$ & $7.01^{\mathrm{c}}$ \\
\hline Significance & $*$ & NS & * & * & NS & $*$ \\
\hline LSD & 3.95 & 0.32 & 12.96 & 78.73 & 9.22 & 5.52 \\
\hline \multicolumn{7}{|l|}{$\begin{array}{l}\text { Swine manure } \\
\qquad\left(\mathrm{t} \mathrm{ha}^{-1}\right)\end{array}$} \\
\hline 0 & $2.42^{a}$ & $0.97^{\mathrm{c}}$ & $27.78^{b}$ & $176.29^{c}$ & $6.66^{\mathrm{c}}$ & $8.14^{\mathrm{c}}$ \\
\hline 5 & $2.40^{\mathrm{a}}$ & $1.46^{\mathrm{b}}$ & $39.17^{\mathrm{ab}}$ & $352.68^{b}$ & $11.57^{\mathrm{bc}}$ & $13.96^{\mathrm{bc}}$ \\
\hline 10 & $4.94^{\mathrm{a}}$ & $1.79^{\mathrm{ab}}$ & $44.83^{\mathrm{a}}$ & $446.35^{a}$ & $24.37^{\mathrm{a}}$ & $18.44^{\mathrm{ab}}$ \\
\hline 15 & $6.94^{\mathrm{a}}$ & $1.99^{\mathrm{a}}$ & $51.67^{\mathrm{a}}$ & $487.84^{a}$ & $19.32^{\mathrm{ab}}$ & $21.89^{\mathrm{a}}$ \\
\hline Significance & NS & ${ }^{*}$ & * & * & * & * \\
\hline LSD & 4.56 & 0.37 & 14.97 & 90.90 & 10.64 & 6.38 \\
\hline
\end{tabular}

Means with the same letter are not significantly different; ${ }^{* *}$ highly significant at $5 \%$ level of probability.

Table 4. Effects of spacing and levels of swine manure application on proximate composition of muskmelon

\begin{tabular}{|c|c|c|c|c|c|c|}
\hline Treatments & $\begin{array}{l}\text { Moisture content } \\
\text { (dry matter basis) }\end{array}$ & $\begin{array}{c}\text { Ash content } \\
(\%)\end{array}$ & $\begin{array}{c}\text { Ether extract } \\
(\%)\end{array}$ & $\begin{array}{c}\text { Crude fibre } \\
(\%)\end{array}$ & Crude protein (\%) & $\begin{array}{c}\text { Nitrogen free extract } \\
(\%)\end{array}$ \\
\hline \multicolumn{7}{|l|}{$\begin{array}{c}\text { Plants spacing } \\
(\mathrm{cm})\end{array}$} \\
\hline $50 \times 50$ & $93.32^{\mathrm{c}}$ & $8.08^{c}$ & $6.80^{\mathrm{b}}$ & $4.18^{c}$ & $6.36^{c}$ & $67.80^{\mathrm{a}}$ \\
\hline $75 \times 75$ & $92.79^{a}$ & $9.80^{\mathrm{b}}$ & $6.61^{c}$ & $4.28^{\mathrm{b}}$ & $7.32^{a}$ & $64.95^{\mathrm{b}}$ \\
\hline $100 \times 100$ & $92.99^{\mathrm{b}}$ & $10.65^{a}$ & $7.55^{\mathrm{a}}$ & $4.43^{\mathrm{a}}$ & $6.85^{\mathrm{b}}$ & $63.31^{\mathrm{c}}$ \\
\hline LSD & 0.01 & 0.08 & 0.08 & 0.08 & 0.01 & 0.01 \\
\hline Significance & $* *$ & ${ }^{* *}$ & ${ }^{* *}$ & ** & ${ }^{* *}$ & ${ }^{* *}$ \\
\hline \multicolumn{7}{|l|}{$\begin{array}{l}\text { Swine manure } \\
\qquad\left(\mathrm{tha}^{-1}\right)\end{array}$} \\
\hline 0 & $93.60^{d}$ & $7.72^{\mathrm{d}}$ & $6.92^{c}$ & $3.78^{d}$ & $5.77^{d}$ & $66.15^{b}$ \\
\hline 5 & $98.87^{b}$ & $10.15^{\mathrm{b}}$ & $7.35^{b}$ & $4.48^{b}$ & $7.01^{b}$ & $63.40^{\mathrm{d}}$ \\
\hline 10 & $98.86^{a}$ & $11.80^{\mathrm{a}}$ & $7.45^{a}$ & $4.68^{a}$ & $8.76^{a}$ & $64.83^{c}$ \\
\hline 15 & $99.06^{c}$ & $8.98^{c}$ & $6.23^{d}$ & $4.22^{c}$ & $5.84^{c}$ & $67.55^{a}$ \\
\hline LSD & 0.01 & 0.09 & 0.09 & 0.09 & 0.01 & 0.01 \\
\hline Significance & ** & $* *$ & $* *$ & ** & ** & ** \\
\hline
\end{tabular}

Means with the same letter are not significantly different; ${ }^{* *}$ highly significant at $5 \%$ level of probability.

Table 5. Effects of spacing and levels of swine manure application on nutrient concentration of muskmelon

\begin{tabular}{|c|c|c|c|c|c|c|}
\hline Treatments & $\begin{array}{c}\text { Nitrogen } \\
(\%)\end{array}$ & $\begin{array}{c}\text { Phosphorus } \\
(\mathrm{mg} / \mathrm{kg})\end{array}$ & $\begin{array}{l}\text { Calcium } \\
(\mathrm{mg} / \mathrm{kg})\end{array}$ & $\begin{array}{c}\text { Magnesium } \\
(\mathrm{mg} / \mathrm{kg})\end{array}$ & Sodium $(\mathrm{mg} / \mathrm{kg})$ & Iron $(\mathrm{mg} / \mathrm{kg})$ \\
\hline \multicolumn{7}{|l|}{$\begin{array}{l}\text { Plants spacing } \\
\qquad(\mathrm{cm})\end{array}$} \\
\hline $50 \times 50$ & $1.02^{\mathrm{c}}$ & $3.45^{\mathrm{c}}$ & $5.92^{\mathrm{c}}$ & $4.08^{c}$ & $1.19^{\mathrm{a}}$ & $0.64^{\mathrm{c}}$ \\
\hline $75 \times 75$ & $1.18^{\mathrm{a}}$ & $3.96^{\mathrm{b}}$ & $6.40^{\mathrm{b}}$ & $4.37^{b}$ & $0.93^{\mathrm{c}}$ & $0.67^{\mathrm{b}}$ \\
\hline $100 \times 100$ & $1.10^{\mathrm{b}}$ & $4.28^{\mathrm{a}}$ & $6.81^{\mathrm{a}}$ & $4.55^{\mathrm{a}}$ & $1.08^{\mathrm{b}}$ & $0.80^{\mathrm{a}}$ \\
\hline LSD & 0.01 & 0.01 & 0.01 & 0.01 & 0.01 & 0.01 \\
\hline Significance & ${ }^{* *}$ & $* *$ & ${ }^{* *}$ & ${ }^{* *}$ & ${ }^{* *}$ & ${ }^{* *}$ \\
\hline \multicolumn{7}{|l|}{$\begin{array}{l}\text { Swine manure } \\
\qquad\left(\mathrm{tha}^{-1}\right)\end{array}$} \\
\hline 0 & $0.93^{\mathrm{d}}$ & $3.38^{\mathrm{d}}$ & $5.80^{d}$ & $4.05^{d}$ & $1.22^{\mathrm{a}}$ & $0.62^{\mathrm{d}}$ \\
\hline 5 & $1.13^{\mathrm{b}}$ & $4.07^{\mathrm{b}}$ & $6.53^{d}$ & $4.44^{\mathrm{b}}$ & $1.02^{\mathrm{c}}$ & $0.77^{\mathrm{b}}$ \\
\hline 10 & $1.14^{\mathrm{a}}$ & $4.55^{\mathrm{a}}$ & $7.34^{\mathrm{a}}$ & $4.78^{\mathrm{a}}$ & $1.12^{\mathrm{b}}$ & $0.79^{\mathrm{a}}$ \\
\hline 15 & $0.94^{\mathrm{c}}$ & $3.71^{\mathrm{c}}$ & $5.84^{\mathrm{c}}$ & $4.07^{\mathrm{c}}$ & $0.92^{\mathrm{d}}$ & $0.65^{c}$ \\
\hline LSD & 0.01 & 0.01 & 0.01 & 0.01 & 0.01 & 0.01 \\
\hline Significance & $* *$ & $* *$ & $* *$ & $* *$ & $* *$ & $* *$ \\
\hline
\end{tabular}


Table 6. Effects of spacing and levels of swine manure application on yield and nutrient uptake of muskmelon

\begin{tabular}{|c|c|c|c|c|c|c|}
\hline Treatments & $\begin{array}{c}\text { Nitrogen } \\
(\%)\end{array}$ & $\begin{array}{c}\text { Phosphorus } \\
(\mathrm{mg} / \mathrm{kg})\end{array}$ & $\begin{array}{l}\text { Calcium } \\
(\mathrm{mg} / \mathrm{kg})\end{array}$ & $\begin{array}{c}\text { Magnesium } \\
(\mathrm{mg} / \mathrm{kg})\end{array}$ & Sodium $(\mathrm{mg} / \mathrm{kg})$ & $\operatorname{Iron}((\mathrm{mg} / \mathrm{kg}))$ \\
\hline \multicolumn{7}{|l|}{$\begin{array}{c}\text { Plant spacing } \\
(\mathrm{cm})\end{array}$} \\
\hline $50 \times 50$ & $13.55 \mathrm{~b}$ & $49.46 \mathrm{~b}$ & $81.22 \mathrm{a}$ & $57.29 b$ & $16.23 a$ & $8.72 \mathrm{c}$ \\
\hline $75 \times 75$ & $17.86 \mathrm{a}$ & $63.64 a$ & $100.48 \mathrm{a}$ & $68.18 \mathrm{a}$ & $14.55 b$ & $10.85 a$ \\
\hline $100 \times 100$ & $13.17 \mathrm{c}$ & $49.37 \mathrm{c}$ & $79.29 \mathrm{c}$ & $52.89 \mathrm{c}$ & $12.46 \mathrm{c}$ & $9.18 \mathrm{~b}$ \\
\hline LSD & 0.01 & 0.01 & 0.01 & 0.01 & 0.01 & 0.01 \\
\hline Significance & $* *$ & ${ }^{* *}$ & ${ }^{* *}$ & ${ }^{* *}$ & ** & ${ }^{* *}$ \\
\hline \multicolumn{7}{|l|}{$\begin{array}{l}\text { Swine manure } \\
\qquad\left(\mathrm{tha}^{-1}\right)\end{array}$} \\
\hline 0 & $14.28 \mathrm{c}$ & $43.71 \mathrm{c}$ & $75.39 \mathrm{c}$ & $52.45 c$ & $15.54 b$ & $7.88 \mathrm{~d}$ \\
\hline 5 & $15.54 b$ & $56.16 \mathrm{~b}$ & $87.58 b$ & $61.29 b$ & $13.80 \mathrm{c}$ & $10.63 b$ \\
\hline 10 & $18.28 \mathrm{a}$ & $70.76 a$ & $112.98 \mathrm{a}$ & $72.73 \mathrm{a}$ & $16.57 \mathrm{a}$ & $11.80 \mathrm{a}$ \\
\hline 15 & $11.34 \mathrm{~d}$ & $45.98 \mathrm{~d}$ & $72.05 \mathrm{~d}$ & $51.35 \mathrm{~d}$ & $11.74 \mathrm{~d}$ & $8.03 c$ \\
\hline LSD & 0.01 & 0.01 & 0.01 & 0.01 & 0.01 & 0.01 \\
\hline Significance & $* *$ & $* *$ & ** & ** & ** & ** \\
\hline
\end{tabular}

Means with same letter are not significantly different; ${ }^{*}$ significant at $5 \%$ level of probability; ${ }^{* *}$ highly significant at $5 \%$ level of probability.

\section{Discussion}

The physical and chemical properties of the soil used for the experiment gave the textural class of sandy loam. The potassium and total nitrogen were all below recommended critical levels of $0.15 \% \mathrm{~N}$ and $0.34 \mathrm{cmol} \mathrm{kg}^{-1} \mathrm{~K}$, while the available phosphorus was a little above the critical concentration $10-16 \mathrm{mg} / \mathrm{kg}$ P for crop production (Adeoye and Akinola, 1985), hence the need for additional nutrient amendments to the soil. In addition, Ozores-Hampton (2012) revealed that organic manure amendments affect soil bulk density, water-holding capacity, soil structure, soil carbon content, macro and micronutrients, $\mathrm{pH}$, soluble salts, cation exchange capacity (CEC) and biological properties (microbial biomass). The increase in vine length at wider spacing could probably be due to the fact that plants in the wider spacing had less competition for growth factors such as nutrients, moisture and sunlight and this is in agreement with the work of Elizabeth and Dennis (1994) who concluded that wider spacing gave the longest vine length and the closest spacing had the shortest vine length. Baloch et al. (2002) observed that reducing plant densities increased the nutrient area per plant and this led to an increase in morphological characters. Also, Morrison et al. (1990) explained further that well-spaced plants received more solar radiation and were therefore more photosynthetically efficient than closely spaced ones. The increase in the number of fruits per plot and subsequent the increase in yield per hectare as a result of decrease in spacing could be due to the fact that closer spacing had adequate ground cover and had higher plant biomass, which aid in the reduction of soil moisture and nutrient loss and this is in support of the work of Aniefiok et al. (2013), who observed from their study on the effects of plant spacing on growth of waterleaf that although wider spacing favoured individual's plant performance morphologically, densely populated plants produced greater mass per unit area compared with less dense plots. They also observed that widely spaced plants had higher moisture content than their closely spaced counterparts. Moniruzzaman et al. (2007) also reported higher seed yield of okra at the narrowest spacing and this also corroborates the findings of Falodun and Ogedegbe (2016) who recorded higher pod yield of okra at narrower spacing compared to wider spacing. The significant increase in some vegetative characters and yield with the $15 \mathrm{t} / \mathrm{ha}$ application of swine manure is similar to the work of Curuk et al. (2004) who reported increases in fruit yield after high manure input compared to customary inorganic fertilization and this further supports the work of Mohammed et al. (2013) who observed an increase in growth and yield of onion applied with moringa extract.

According to Aisha et al. (2007), crops cultivated with organic manures are not only free from harmful chemicals; they are also safer, healthier and tastier. They are of high nutritional quality and are devoid of all forms of pollution that arise from agricultural techniques. Apart from supplying plant nutrients, Akinfasoye and Akanbi (2005) also justified that they improve soil physical and microbial properties and eliminate pollution of underground water.

Moisture content determination is an integral part of the proximate composition analysis of food. The high moisture content in muskemelon $(92.79-99.06 \%)$ is in agreement with the finding of Adetuyi et al. (2011) in their study on okra. Also this is in accordance with the finding of Gopalan et al. (2007) (89\%) and (Nwachukwu et al., 2014) (88.47\%). Moisture content of any food is an index of its water activity and is used as a measure of stability and susceptibility to microbial contamination (Uyoh et al., 2013). The high moisture content in vegetables makes them vulnerable to microbial attack, hence spoilage (Nwofia et al., 2012). This high moisture content also implies that dehydration would increase the relative concentrations of other food nutrient and therefore improve the shelf-life and preservation of the fruits (Aruah et al., 2012).

The mean crude protein content in the present study (3.78-4.68\%) was lower than that reported by Abolaji et al. (2017) (19.85\%) for grain amaranth, but almost comparable with the findings of Nwachukwu et al. (2014) 
296

$(4.81 \mathrm{~g} / 100 \mathrm{~g})$. Muskemelon can be considered a high protein vegetable when compared with Gnetum africanum $(1.5 \mathrm{~g} / 100 \mathrm{~g})$ and Pterocarpus $(2.0 \mathrm{~g} / 100 \mathrm{~g})$ (Nzikou et al., 2006) and this implies that muskemelon fruits can serve as a good source of protein.

Nwofia et al. (2012) reported that diet is nutritionally satisfactory, if it contains high caloric value and a sufficient amount of protein. The ash content is a measure of the nutritionally important mineral contents present in the food material. The level of ash content ranged from $7.72 \%$ to $11.80 \%$; on dry weight basis, this result showed that the sample contained a considerable amount of ash, which indicates that that muskemelon would provide essential valuable minerals, needed for body development. The mean ash content obtained hereby was higher than that reported by Abolaji et al. (2017), 2.25\% respectively.

Dietary fats function in the increase of palatability of food by absorbing and retaining flavors (Antia et al., 2006). Excess consumption of fat has been implicated in certain cardiovascular disorders such as atherosclerosis, cancer and aging; in this regard, the consumption of muskemelon diet should be encouraged to reduce the risk of above diseases in human. The fibre content of muskemelon in the hereby study can be considered high when compared with Amarantus hybridus $(1.6 \mathrm{~g} / 100 \mathrm{~g})$, which may suggest that consumption of muskemelon will improve digestibility and absorption processes in large intestine, helping to stimulate peristalsis, thereby preventing constipation.

The increase in the moisture content, crude fibre and crude protein as a result of increase in manure levels is an indication that manure improves the quality of crops. The highest nutrient concentration in the wider spacing of 100 $\times 100 \mathrm{~cm}$ and higher uptakes observed with $75 \times 75 \mathrm{~cm}$ plant spacing of most nutrient elements could probably be indications that plants at these spacing distances might have experienced better soil conditions to enable them absorb these nutrients effectively. However, the highest yield per hectare obtained at the narrowest spacing of $50 \times 50 \mathrm{~cm}$ earlier observed in this study could be due to the fact that closer spacing had adequate ground cover and higher plant biomass. The increase in nutrient concentration and uptake up to $10 \mathrm{t} / \mathrm{ha}$ suggests that the fertilizer application enhances the uptake of nutrients up to a certain optimum fertilizer levels. This corroborates the results of Falodun and Egharevba (2017). They attributed the better nutrient uptake at higher levels to the availability of adequate amount of nutrients in the soil at these levels and this improved the plant capacity to absorb the nutrients.

\section{Conclusions}

Application of swine manure at higher application rate improved muskmelon yield. Closest spacing tested of $50 \times$ $50 \mathrm{~cm}$ produced the highest yield, but smaller fruits, probably because of higher number of plants per hectare. The spacing of $75 \times 75 \mathrm{~cm}$ could also be adopted, as it produced higher fruit weight compared to the other treatments evaluated. Swine manure rate at $10 \mathrm{t} / \mathrm{ha}$ gave the highest yield and best qualities of muskmelon in the present study.

\section{Conflict of Interest}

The authors declare that there are no conflicts of interest related to this article.

\section{References}

Abolaji GT, Olooto DT, Ogundele DT, Williams FE (2017). Nutritional characterisation of grain amaranth grown in Nigeria for food security and healthy living. Agrosearch 17(2):1-10.

Adeoye GO, Agboola AA (1985). Critical levels for soil pH, available P, K, $\mathrm{Zn}$ and Mn and maize ear-leaf content of $\mathrm{P}, \mathrm{Cu}$ and Mn in sedimentary soils of South-Western Nigeria Nutrient Cycling in Agroecosystems 6(1):65-71.

Adetuyi FO, Osagie AU, Adekunle AT (2011). Nutrient, antinutrient, mineral and bioavailability of okra Abelmoschus esculentus (L) Moench. American Journal of Food Nutrition 1:49-54.

Aisha AH, Rizk FA, Shaheen AM, Abdel Mouty MM (2007). Onion plant growth, bulbs yield and its physical and chemical properties as affected by organic and natural fertilizers. Research Journal of Agricultural and Biological Sciences 3(5):380-388.

Akinfasoye JA, Akanbi WB (2005). Effect of organic fertilizer and spacing on growth and yield of celosia (Celosia argentea L.). Proceedings 23rd HORTSONConference, Port Harcourt.

Aniefiok EU, Idorenyin AU, John OS (2013). Effects of poultry manure and plant spacing on the growth and yield of waterleaf (Talinum fructicosum (L.) Juss).Journal of Agronomy 12:146-152.

Antia BS, Akpan EJ, Okon PA, Umoren IU (2006). Nutritive and anti-nutritive evaluation of sweet potatoes (Ipomoea batatas) leaves. Pakistan Journal of Nutrition 5:166-168.

AOAC (1990). Official Methods of Analysis. 14th edition, Association of Analytical Chemists Washington DC.

Aruah BC, Uguru MI, Oyiga BC (2011). Nutritional evaluation of some Nigerian pumpkins (Cucurbita spp.). Fruit, Vegetable Cereal Science. Biotechnology 5:6471.

Baloch AW, Soomro AM, Javed MA, Ahmed M, Bughio HR, Bughio MS, Mastoi NN (2002). Optimum plant density for high yield in rice (Oryzasativa L). Asian Journal of PlantScience 1:25-27.

Bray RH, Kurtz LT (1945). Determination of total organic and available forms of Phosphorusin soils. Soil Science 59:39-45.

Bulluck LR III, Brosius M, Evanylo GK, Ristaino JB (2002). Organic and synthetic fertility amendments influence soil microbial, physical, and chemical properties on organic and conventional farms. Applied Soil Ecology 19:147-160.

Cakmak I (2002). Plant nutrition research: Priorities to meet human needs for food in sustainable ways. Plant and Soil 247:3-24.

Cürük S, Sermenli T, Mavi K, Evrendilek F (2004). Yield and fruit quality of watermelon (Citrullus lanatus (Thumb.) Matsum. \& Nakai) and melon (Cucumis melo L.) under protected organic and conventional farming systems in a Mediterranean region of Turkey. Biological Agriculture\&Horticulture 22:173-183. 
Davis GN, Meinert UGH (1965). The effect of plant spacing and fruit pruning on the fruits of P.M.R no. 45 cantaloupe. Proceeding America Society Horticulture Science 87:299-302.

El-Desuki M, Shafeek MR, Sawan OMM (2000). Effect of organic and mineral fertilization on growth, yield and quality of cantaloupe (Cucumis melo L.). Journal on Applied Science 15(12):585-603.

Falodun EJ, Ogedegbe SA (2016). Effects of planting spacing and harvest intervals on growth,yield and quality of okra (Abelmoschus esculentus (L) Moench). Applied Tropical Agriculture 21(1):111-115.

Falodun EJ, Egharevba RKA (2017). Nutrient concentration, uptake and yield of onion (Allium cepa $\mathrm{L}$.) as affected by manures types and rates of application.Journal of Agriculture, Forestry and Fisheries 16(2):14-17.

Fernandes ALT, Rodrigues GP, Testezlaf R (2003). Mineral and organomineral fertigation in relation to quality of greenhouse cultivated melon. Scientia Agricola 60(1):149-154.

Gopalan C, Sastri SBV, Balasubramanian S (2007). Nutritive value of Indian foods. National Institute of Nutrition (NIN), ICMR, India.

Hodges DM, Lester GE (2006). Comparisons between orange- and greenfleshed non-netted and orange-fleshed netted muskmelons: Antioxidant changes following different harvest and storage periods. Journal of the American Society for Horticultural Science 131: 10-117.

Jackson ML (1969). Soil chemical analysis. Constable and Co Ltd, London, U.K.

Knavel DE (1991). Growth, development and yield potential of short internode muskmelon. Journal America Society Horticulture Science 113:595-599.

Maynard ET, Scott WD (1998). Plant spacing affects yield of superstar muskmelon. HortScience 33(1):52-54.

Melero S, Porras JCR, Herencia JF, Madejon E (2006). Chemical and biochemical properties in a silty loam soil under conventional and organic management. Soil and Tillage Research 90:162-170.

Mohammed R, Olorukooba MM, Akinyaju JA, Kambai EA (2013). Evaluation of different concentrations and frequency of foliar application of moringa extract on growth and yield of onion (Allium cepa). Agrosearch 3:196-201.

Moniruzzaman M, Uddin MZ, Choudhury AK (2007). Response ofOkra seed crop to sowing time and plant spacing in South Eastern hilly region of Bangladesh. Bangladesh Journal of Agricultural Research 32(3):393402.
Morra L, Bilotto M, Magnifico V (2003). Long term effects of soil organic amendment or mineral fertilization on vegetable crops productivity in tunnel. Acta Horticulturae 614:781-785.

Morrison MJ, McVetty PBE, Scarth R (1990). Effect of altering plant density on growth characteristics of summer rape. Canadaian Journal of PlantScience 70:139-149.

Murphy J, Riley JP (1962). Modified. single solution methods for determination of phosphorus in natural water. Analytical Chemistry Acta 27:31-36.

Nwachukwu EC, Nulit R, Go R (2014). Nutritional and biochemical properties of Malaysian okra variety. Advanced Medicinal Plant Research 2:16-19.

Nwofia GE,Nwogu Victoria N,Nwofia BK(2012). Nutritional variation in fruits and seeds of pumpkins (Cucurbita spp.) accessions from Nigeria. Pakistan Journal of Nutrition 11:946-956.

Nzikou JM, Mvoula-Tsieri M, Matouba E, Ouamba JM, Kapseu C, Parmentier M, Desobry S (2006). A study on gumbo seed grown in Congo Brazzaville for its food and industrial applications. African Journal of Biotechnology 5(24):2469-2475.

Ozores-Hampton M (2012). Effect of spacing and variety on yield and fruit quality of pepper grown with seepage irrigation in Florida sandy soil. $21^{\star}$ International Pepper Conference at Naples, Florida 21:40.

Pacini C, Wossink A, Giesen G, Vazzana C, Huirne R(2003). Evaluation of sustainability of organic, integrated and conventional farming systems: A farm and field-scale analysis. Agriculture, Ecosystems \& Environment 95:273-288.

Piccolo A, Nardi S, Concheri G (1992). Structural characteristics of humic substances as related to nitrate uptake and growth regulation in plant systems. Soil Biology \& Biochemistry 24:373-380.

USDA (2014). Nutrition Facts for $100 \mathrm{~g}$ of melons, cantaloupe, raw [includes USDA commodity food A415]. Conde Nast for the USDA National Nutrient Database, version SR-21.

Uyoh EA, Ita EE, Nwofia GE (2013). Evaluation of the chemical composition of Tetrapleura tetraptera (Schum and Thonn.) Tuab. accessions from Cross River State, Nigeria. International Journal of Medicinal and Aromatic Plants 3:386-394.

Walkley J, Black JP (1962). A critical examination of a rapid method for determining organic carbon in soils. Effects of variation in digestion conditions and of organic carbon constituents. Soil Science 63:251-263. 